\title{
Chronology of the deglaciation of the Zackenberg area, NE Greenland
}

J. Garcia-Oteyza ${ }^{1 *}$, M. Oliva ${ }^{1}$, D. Palacios ${ }^{2}$, J-M. Fernández-Fernández ${ }^{3}$, I. Schimmelpfennig ${ }^{4}$, N. Andrés ${ }^{2}$, D. Antoniades $^{5}$, H. H. Christiansen ${ }^{6}$, O. Humlum ${ }^{6}$, L. Léanni ${ }^{4}$; V. Jomelli ${ }^{4}$, J. Ruiz-Fernández ${ }^{7}$, ASTER Team ${ }^{4,8}$

${ }^{1}$ Department of Geography, Universitat de Barcelona, Catalonia, Spain

${ }^{2}$ Department of Geography, Complutense University of Madrid, Madrid, Spain

${ }^{3}$ Centre for Geographical Studies, IGOT, Universidade de Lisboa, Lisbon, Portugal

${ }^{4}$ Aix-Marseille Université, CNRS, IRD, INRAE, Coll. France, UM 34 CEREGE, Aix-en-Provence, France

${ }^{5}$ Department of Geography \& Centre for Northern Studies, Université Laval, Quebec, Canada

${ }^{6}$ Arctic Geology Department, University Centre in Svalbard, Longyearbyen, Norway

${ }^{7}$ Department of Geography, University of Oviedo, Asturias, Spain

${ }^{8}$ Consortium: Georges Aumaître, Didier Bourlès, Karim Keddadouche

The Greenland Ice Sheet (GrIS) plays a key role in the global climate system. Its response to recent warming concerns the scientific community due to its potential contribution to the global sea-level rise, oceanographic changes and the related heat distribution in the atmosphere. Therefore, a better understanding of the GrIS response to past glacial oscillations can provide insights into its sensitivity to rapidly changing climates. Past natural GrIS dynamics are still poorly constrained, and there are important knowledge gaps in the spatio-temporal pattern of its past fluctuations, especially on the NE margins, in response to climate variability. Here, we present new records of past GRIS extents and a detailed space-time reconstruction of the deglaciation process in the Zackenberg Valley $\left(74^{\circ} \mathrm{N}, 20^{\circ} \mathrm{E}\right)$, NE Greenland, based on geomorphological mapping combined with a new dataset of 39 10Be cosmic-ray exposure (CRE) ages of moraine boulders, polished surfaces, and erratic boulders. Our dataset records glacial oscillations from the Last Glacial Cycle to the Early Holocene. Geomorphic evidence at the summit surfaces reveal that glaciers were significantly thicker $(>800 \mathrm{~m})$ at ca. $80 \mathrm{ka}$, when valleys and fjords were ice-covered and only the highest peaks remained ice-free. The Zackenberg outlet glacier must have been slightly smaller during the Last Glacial Maximum, although no glacial records of this period were found. Samples from moraine boulders indicate rapid and massive deglaciation of the Zackenberg Valley slopes by ca. 14 ka, during the Bølling-Allerød interstadial. Ice thinning exposed the upper and intermediate slopes surrounding the valley floor, while stabilization phases within the long-term glacial retreat favoured the development of several moraine ridges. At the end of the Younger Dryas, by ca. $12 \mathrm{ka}$, a glacier readvance favoured the development of the lowest moraine ridges of the slopes, connected with the outermost moraine system on the valley floor. Within the limits of this moraine, a debris-covered glacier formed due to the intense paraglacial readjustment of rock slopes and moraines triggered by glacier thinning. This process favoured the degradation of the moraine ridges on the slopes, supplying large amounts of debris to the shrinking glacier. By $\sim 10.5 \mathrm{ka}$, the last remnants of glacial ice disappeared from the Zackenberg Valley floor, exposing polished bedrock outcrops and leaving scattered erratic boulders. Higher temperatures also favoured the irregular collapse of the debris-covered glacier, transforming this area into a hummocky terrain. This deglaciation chronology shows a particularly intense recession during the Bølling-Allerød and Early Holocene, a path that is broadly similar to that observed in other sites across NE Greenland. 